\title{
SPRAWOZDANIE Z OGÓLNOPOLSKIEJ KONFERENCJI NAUKOWEJ „PRAWNE ASPEKTY GOSPODAROWANIA ZASOBAMI ŚRODOWISKA" - ZJAZD KATEDR PRAWA OCHRONY ŚRODOWISKA, TORUŃ 15-16 MAJA 2014 R.
}

\section{THE REPORT ON THE NATIONAL CONFERENCE "THE LEGAL ASPECTS OF ENVIRONMENTAL RESOURCES MANAGEMENT" - THE CONGRESS OF DEPARTMENTS OF ENVIRONMENTAL PROTECTION LAW, TORUŃ 15-16TH MAY 2014}

\section{STRESZCZENIE}

W dniach 15-16 maja 2014 r. w Toruniu odbyła się ogólnopolska konferencja naukowa „Prawne aspekty gospodarowania zasobami

" Doktor nauk prawnych, adiunkt w Katedrze Prawa Ochrony Środowiska Wydziału Prawa i Administracji Uniwersytetu Mikołaja Kopernika w Toruniu. 
środowiska" - Zjazd Katedr Prawa Ochrony Środowiska, zorganizowana przez Katedrę Prawa Ochrony Środowiska WPiA UMK w Toruniu we współpracy z Wojewódzkim Funduszem Ochrony Środowiska i Gospodarki Wodnej w Toruniu. Konferencja stanowiła forum wymiany poglądów i prezentacji wyników badań naukowych na temat gospodarowania zasobami środowiska. Wydarzenie to stanowiło również okazję do wymiany doświadczeń między przedstawicielami teoretyków prawa ochrony środowiska oraz praktyków (sędziów sądów administracyjnych oraz pracowników organów administracji publicznej).

\section{Słowa kluczowe}

Prawo ochrony środowiska; prawne aspekty gospodarowania zasobami środowiska; konferencja naukowa.

\section{ABSTRACT}

Between 15-16th May, 2014 a national scientific conference "The legal aspects of environmental resources management" took place in Torun - The congress of Departments of Environmental Protection Law. The conference was organized by the Department of Environmental Protection Law of Faculty of Law and Administration of Nicolaus Copernicus University in Torun in cooperation with the Voivodeship Fund for Environmental Protection and Water Management in Toruń. The conference provided a forum for the exchange of views and presentation of the research results on environmental resources management. It was also an opportunity to exchange experiences between representatives of environmental protection law theorists and practitioners (judges of administrative courts and employees of public administration).

\section{Keywords}

Environmental law; legal aspects of environmental resources management; scientific conference.

W dniach 15-16 maja 2014 r. w Toruniu odbyła się ogólnopolska konferencja naukowa „Prawne aspekty gospodarowania zasobami środowiska” - Zjazd Katedr Prawa Ochrony Środowiska. Wydarzenie to zostało zorganizowane przez Katedrę Prawa Ochrony Środowiska WPiA UMK w Toruniu we współpracy 
z Wojewódzkim Funduszem Ochrony Środowiska i Gospodarki Wodnej w Toruniu.

Konferencja została objęta honorowym patronatem:

- pana Andrzeja Rzeplińskiego - Prezesa Trybunału Konstytucyjnego,

- pana Romana Hausera - Prezesa Naczelnego Sądu Administracyjnego,

- pana Michała Kiełszni - Generalnego Dyrektora Ochrony Środowiska,

- pana Andrzeja Jagusiewicza - Głównego Inspektora Ochrony Środowiska,

- pana Adama Wasiaka - Dyrektora Generalnego Lasów Państwowych,

- pana Piotra Litwy - Prezesa Wyższego Urzędu Górniczego,

- pana Witolda Sumisławskiego - Prezesa Krajowego Zarządu Gospodarki Wodnej,

- pana Piotra Całbeckiego - Marszałka Województwa Kujawsko-Pomorskiego,

- pani Emilii Kawki-Patek - Prezes Zarządu Wojewódzkiego Funduszu Ochrony Środowiska i Gospodarki Wodnej w Toruniu,

- pana Michała Zaleskiego - Prezydenta Miasta Torunia,

- pana Tomasza Justyńskiego - Dziekana Wydziału Prawa i Administracji UMK w Toruniu.

Członkami Komitetu Naukowego zostali: pan prof. dr hab. Marek Górski; pan prof. dr hab. Aleksander Lipiński; pan prof. dr hab. Wojciech Radecki; pan prof. dr hab. Bartosz Rakoczy; pan dr hab. Zbigniew Bukowski, prof. UKW; pani dr hab. Ewa K. Czech, prof. UwB; oraz pan dr hab. Jerzy Stelmasiak, prof. UMCS. Natomiast w składzie Komitetu Organizacyjnego znaleźli się: jako Przewodniczący - pan prof. dr hab. Bartosz Rakoczy (Kierownik Katedry Prawa Ochrony Środowiska UMK w Toruniu) i jako Wiceprzewodniczący - pan mgr Wojciech Kuliński (Zastępca Prezesa Wojewódzkiego Funduszu Ochrony Środowiska i Gospodarki Wodnej w Toruniu), oraz pozostali członkowie - członkowie: dr Karolina Karpus (adiunkt KPOŚ WPiA UMK), dr Małgorzata Szalewska (adiunkt KPOŚ WPiA UMK), mgr Mar- 
tyna Walas (doktorantka w KPOŚ WPiA UMK), mgr Jacek Pakuła (doktorant w KPOŚ WPiA UMK), stud. Bartłomiej Gmaj i stud. Anna Kotańska.

Zamiarem organizatorów konferencji było stworzenie forum prezentacji wyników badań naukowych, jak również konfrontacji założeń teoretyków prawa z praktyką, w tym również przedstawicielami administracji ochrony środowiska oraz przedsiębiorców, w odniesieniu do niezwykle istotnej problematyki, jaką stanowią prawne aspekty gospodarowania zasobami środowiska. Zasada zrównoważonego rozwoju wyznacza bowiem władzy publicznej kierunek poszukiwań równowagi między potrzebami człowieka a zadaniem, jakim jest ochrona środowiska, jako dobra wspólnego. Prawo stanowi w tym zakresie podstawowy instrument odzwierciedlający rezultaty tych poszukiwań, składających się na politykę ochrony środowiska państwa polskiego. Stanowienie właściwie skonstruowanych, a więc i efektywnych w praktyce rozwiązań prawnych, których przedmiotem jest zarządzanie środowiskiem i jego ochrona, stanowią kluczowy obszar badawczy polskiej nauki prawa ochrony środowiska. Prowadzone w tym zakresie badania naukowe teoretyków prawa ochrony środowiska winny być stale konfrontowane z doświadczeniami praktyków sędziów sądów administracyjnych i pracowników organów administracji publicznej z jednej strony, a adresatami tych norm (w tym zwłaszcza podmiotami korzystającymi ze środowiska) z drugiej strony. Z tego też względu konferencja, połączona ze zjazdem katedr prawa ochrony środowiska polskich uczelni - zgromadziła nie tylko pracowników naukowych ośrodków akademickich, lecz także przedstawicieli sądów administracyjnych oraz pracowników administracji ochrony środowiska.

Debata $\mathrm{w}$ ramach konferencji obejmowała następujące obszary tematyczne: instrumenty polityki i prawa ochrony środowiska (w tym odpowiedzialność prawna w ochronie środowiska, ustrój administracji ochrony środowiska, procedura oceny oddziaływania na środowisko); ochrona przyrody (w tym zrównoważone użytkowanie oraz odnawianie zasobów, tworów i składników przyrody, ochrona krajobrazu, trwale 2/2014 zrównoważona gospodarkę leśna oraz gospodarka łowiecka); 
gospodarka wodna (w tym kształtowanie i ochrona zasobów wodnych i korzystanie z wód oraz zarządzanie zasobami wodnymi); gospodarowanie kopalinami; gospodarowanie odpadami; przeciwdziałanie zanieczyszczeniom i ochrona klimatu; finansowanie ochrony środowiska - w Polsce, w Unii Europejskiej i na świecie (ekologiczna reforma podatkowa, podatki ekologiczne); środowisko i przedsiębiorca (w tym problematyka odnawialnych źródeł energii, „zielonych” zamówień publicznych oraz dozwolonej pomocy publicznej na ochronę środowiska).

W pierwszym dniu konferencji odbyły się trzy panele dyskusyjne, prowadzone przez: pana prof. dr. hab. Marka Górskiego, pana prof. dr. hab. Wojciecha Radeckiego oraz pana prof. dr. hab. Bartosza Rakoczego. W ich trakcie przedstawione zostały następujące wystąpienia:

- Pojęcie gospodarowania zasobami środowiska - prof. dr hab. Bartosz Rakoczy (Uniwersytet Mikołaja Kopernika w Toruniu);

- „Strategiczne zasoby naturalne” jako dobra publiczne dr Anna Haładyj, mgr Jacek Trzewik (Katolicki Uniwersytet Lubelski Jana Pawła II);

- Prawne aspekty gospodarowania zasobami środowiska - kierunki zmian $w$ polskim prawie $w$ ostatnim 15-leciu a perspektywy na przyszłość - dr hab. Zbigniew Bukowski, prof. UKW (Uniwersytet Kazimierza Wielkiego w Bydgoszczy);

- O potrzebie wypracowania modelu kodyfikacji prawa ochrony środowiska - dr hab. Piotr Korzeniowski, prof. UŁ (Uniwersytet Łódzki);

- Eksploatacja zasobów środowiska $w$ kontekście zasady przezorności - mgr Ilona Przybojewska (Uniwersytet Jagielloński);

- Korzystanie z zasobów wód zgodnie z zasada racjonalnej gospodarki rybackiej - prof. dr hab. Wojciech Radecki (INP PAN);

- Orzecznictwo sądów administracyjnych z zakresu wprowadzania ścieków przemystowych i komunalnych do wód - dr hab. Jerzy Rotko, prof. INP PAN (INP PAN); 
- Konsekwencje prawne objęcia parku narodowego obszarem Natura 2000 - dr hab. Adam Habuda, prof. INP PAN (INP PAN);

- Opłata podwyższona za naruszenie warunków wydobywania piasków i żwirów na własne potrzeby - dr Gabriel Radecki (Wojewódzki Sąd Administracyjny w Gliwicach/ /Uniwersytet Śląski);

- Gospodarowanie nieruchomościami Skarbu Państwa w parkach narodowych - mgr Łukasz Ciołek, mgr Dorota Pyrzanowska (Uniwersytet Przyrodniczo-Humanistyczny w Siedlcach);

- O potrzebie regulacji prawnośrodowiskowej $w$ zakresie przeciwdziałania ucią̇̇liwości zapachowej - dr Mariusz Baran (Uniwersytet Jagielloński);

- Konstytucyjność wybranych norm Prawa geologicznego i górniczego - mgr Hubert Schwarz (Amadeus Kancelaria Prawnicza);

- Nielegalne wydobywanie kopalin - prof. dr hab. Aleksander Lipiński (Uniwersytet Śląski w Katowicach);

- Wybrane aspekty wydobywania kruszywa naturalnego ze złóż zlokalizowanych na dnie lub pod dnem akwenów na śródlądowych wodach powierzchniowych - mgr Łukasz Iwański (Wyższy Urząd Górniczy);

- Geopolityczno-prawne uwarunkowania gospodarki zasobami Federacji Rosyjskiej - dr Magdalena Micińska-Bojarek (Kujawsko-Pomorska Szkoła Wyższa w Bydgoszczy);

- Globalne prawo zrównoważonego rozwoju i lokalne wdrożenie na przykładzie wsparcia mikroinstalacji OZE - dr Leszek Karski (Uniwersytet Kardynała Stefana Wyszyńskiego w Warszawie);

- Wybrane aspekty orzecznicze dotyczace energetyki wiatrowej - dr Zygmunt Wiśniewski (Wojewódzki Sąd Administracyjny we Wrocławiu/Politechnika Wrocławska);

- Decyzja o środowiskowych uwarunkowaniach na realizację przedsięwzięcia $w$ świetle orzecznictwa Naczelnego Sądu Administracyjnego - dr hab. Jerzy Stelmasiak, prof. UMCS (UMCS w Lublinie), dr Agnieszka Wilk-Ilewicz (Naczelny 2/2014 Sąd Administracyjny/Politechnika Warszawska). 
W drugim dniu konferencji odbyły się dwa panele dyskusyjne, kierowane przez pana dr hab. Zbigniewa Bukowskiego, prof. UKW oraz panią dr hab. Ewę K. Czech, prof. UwB. W ich trakcie przedstawione zostały następujące referaty:

- Korzystanie z lasów a trwale zrównoważona gospodarka leśna - mgr Martyna Walas (UMK w Toruniu);

- Odpowiedzialność z tytułu historycznego zanieczyszczenia ziemi - zagadnienia sporne - dr hab. Ewa K. Czech, prof. UwB (Uniwersytet w Białymstoku);

- Historyczne zanieczyszczenie powierzchni ziemi - dr hab. Maciej Rudnicki, prof. KUL, dr Piotr Zacharczuk (Katolicki Uniwersytet Lubelski Jana Pawła II);

- Koncepcja konstrukcji opłaty za odbieranie i zagospodarowanie odpadów komunalnych - prof. dr hab. Marek Górski (Uniwersytet Szczeciński);

- Prawne zasady postępowania z odpadami wydobywczy$m i-d r$ hab. Grzegorz Dobrowolski (Uniwersytet Śląski w Katowicach);

- Rozszerzona odpowiedzialność producenta $w$ świetle hierarchii sposobów postępowania z odpadami - dr Karolina Karpus (UMK w Toruniu);

- Partycypacja społeczna $w$ gospodarowaniu zasobami środowiska - dr Małgorzata Szalewska (UMK w Toruniu);

- Odpowiedzialność dyscyplinarna wykonywana przez podmioty realizujące zadania zlecone z zakresu administracji publicznej wobec swoich członków na przykładzie działalności samorządu korporacyjnego myśliwych jakim jest PZŁ - dr Roman Stec (Uniwersytet Przyrodniczo-Humanistyczny w Siedlcach);

- Status prawny wojewódzkich funduszy ochrony środowiska i gospodarki wodnej - mgr Jerzy Jamiołkowski (Wojewódzki Fundusz Ochrony Środowiska i Gospodarki Wodnej w Toruniu);

- Edukacja ekologiczna a gospodarowanie zasobami środowiska - mgr Jacek Pakuła (UMK w Toruniu).

W konferencji udział wzięło blisko 140 uczestników. Debacie naukowej towarzyszyły również tradycyjne spotkania integracyjne: zwiedzanie zabytkowej starówki miasta Torunia, 
wpisanej na Listę Światowego Dziedzictwa UNESCO oraz uroczysta kolacja. Uczestnicy mieli także okazję, dzięki otrzymanym materiałom konferencyjny, zapoznać się z informacjami na temat dziedzictwa kulturowego i przyrodniczego województwa kujawsko-pomorskiego - miasto Toruń to jedna ze stolic tego województwa.

Bezpośrednim owocem wydarzenia, jakim była ogólnopolska konferencja naukowa „Prawne aspekty gospodarowania zasobami środowiska” - Zjazd Katedr Prawa Ochrony Środowiska, będzie monografia naukowa (obejmująca blisko 50 arkuszy wydawniczych). Jej wydanie, wspólnie z toruńskim Wydawnictwem TNOIK „Dom Organizatora”, planowane jest na przełomie jesieni i zimy $2014 \mathrm{r}$.

Kontakt e-mail:

kkarpus@law.uni.torun.pl 